SAndra L. Hofferth and John F. SANDBerg

University of Michigan

\title{
How American Children Spend Their Time
}

The purpose of this article is to examine how American children under age 13 spend their time, sources of variation in time use, and associations with achievement and behavior. Data come from the 1997 Child Development Supplement to the Panel Study of Income Dynamics. The results suggest that parents' characteristics and decisions regarding marriage, family size, and employment affect the time children spend in educational, structured, and family activities, which may affect their school achievement. Learning activities such as reading for pleasure are associated with higher achievement, as is structured time spent playing sports and in social activities. Family time spent at meals and time spent sleeping are linked to fewer behavior problems, as measured by the child's score on the Behavior Problems Index. The results support common language and myth about the optimal use of time for child development.

We often assume that how children spend their time affects their cognitive and social development. Much of our language refers to children's behavior in terms of time-whether they spend too little time studying, reading, or helping around the house or too much time watching television and hanging out with friends. Despite the use of language in which time is the accepted cultural medium for communicating about children's ac-

Institute for Social Research, University of Michigan, P.O Box 1248, Ann Arbor, MI 48106-1248. (Hofferth@ umich.edu).

Key Words: achievement, behavior problems, children, time use. tivities and behavior, however, time is rarely studied. This article takes advantage of national data collected in 1997 to describe how younger and older children under age 13 spend their time, what factors are associated with these time expenditures, and whether variations in time use are associated with children's achievement and behavior.

\section{BACKGROUND}

The development of a child from infancy to adulthood requires substantial parental and community investments of time, money, and psychosocial or emotional capital (Haveman \& Wolfe, 1994). Besides providing opportunities for engagement with others, activities provide contexts for learning (Larson \& Verma, 1999). Each context engages participants in a set of behaviors and rules and results in learning skills and a body of knowledge. Much research focuses on the acquisition of literacy, numeracy, and problem-solving skills. In addition to cognitive skills, activities such as play and conversation provide opportunities for developing social and emotional skills. The quantity of time serves as an estimate of exposure to different social experiences, with more time leading to greater absorption of the skills and knowledge of that context. Although we may know the demographic and economic characteristics of children's families and the communities where they live and attend school, we rarely know how individual children spend their time (Larson \& Verma). Thus, children's own investments and exposure and their links to achievement and emotional growth are unknown. 
In this article, we address four key areas of children's activities: (a) school and day-care time, (b) discretionary time in free play versus organized activities, (c) time in outside-of-school learning activities, and (d) time spent in family activities.

\section{Time Spent in School Settings}

One of the critical concerns of parents is optimizing children's learning in formal settings. Educational research has focused on such factors as expenditures per capita, class size, and teacher qualifications (Hanushek, 1989), but less attention has been paid to how the amount of time children spend in school may be related to achievement on standardized tests. American children spend much less time in school and studying than do Chinese and Japanese children (Fuligni \& Stevenson, 1995; Juster \& Stafford, 1991). It is hypothesized that this difference may account for the substantial differences in achievement between children in both countries. Yet time in school-based settings has increased over the past several decades in the United States (Hofferth, 1996). We examine the amount of time children spent in school and day care in 1997, how family and individual factors are linked to in-school time, and whether school and day-care time are linked to achievement on standardized tests.

\section{Free Play versus Organized Activities}

Children do not learn only in formal settings. For young children, play is their work. Besides motor skills, in play children develop initiative, self-regulation, and social skills (Larson \& Verma, 1999). Recent research has pointed out both the importance of physical activity to child development (Bredekamp \& Copple, 1997) and the sedentary nature of many children's lives (Pellegrini \& Smith, 1998). In this research, playing is a broad category that includes playing cards, board games, and puzzles; playing social games such as jump rope; playing pretend games; playing with toys; and unspecified indoor and outdoor play. It also includes playing computer games and surfing the Internet. A related category, outdoor activities, includes gardening, boating and camping, picnicking, pleasure drives, walking, and hiking. The types of activities in which children engage are likely to be shaped by their current family context, including maternal employment, education, and family structure. We ask here whether the amount of time spent in play or other free-time activities matters to children's achievement and behavior.

Instead of these unstructured activities, children today may be spending a large fraction of time in highly structured activities, such as sports programs, church-sponsored activities, and a broad category called "visiting." Major legislative efforts made in the 1970s to improve girls' opportunities should show up today in only a small gender gap in sports at the elementary school level. Organizations such as Little League and Gymboree promote participation in sports, but parents have little guidance as to their contribution to child development. Church activities include attending church as well as participating in churchsponsored meetings. Visiting is included as a structured activity because it includes participation in (non-church-sponsored) youth clubs and organizations. Such activities are expected to promote children's achievement and behavior (Task Force on Youth Development and Community Programs, 1992).

\section{Out-of-School Learning Activities}

Reading is an activity that has been shown to be strongly linked to children's scores on standard verbal achievement tests (Snow, Burns \& Griffin, 1998; U.S. Department of Education, 1999), as has studying (Keith, Reimers, Fehrmann, Pottebaum, \& Aubey, 1986). Watching a lot of television, in contrast, has been linked to lower cognitive test scores (Timmer, Eccles, \& O'Brien, 1985). Several studies show that more television viewing is associated with less time spent in activities such as reading and studying (Koolstra \& Van Der Voort, 1996), which may partially explain its negative effect. In the early 1980s (Timmer et al.), children spent only 8 minutes per day reading for pleasure, whereas 2.3 hours were spent watching television. It is important to explore what factors affect time spent in these activities and what difference these activities make to children's achievement.

\section{Family Activities}

Family activities, including household work, household conversations, and mealtime provide important opportunities for children to participate in household routines. Small amounts of market work, such as babysitting and newspaper delivery, can also provide training in important skills and responsibilities at a young age. Although it is ar- 
gued that youth need to be engaged in the lives of their families and communities (Zill, Collins, West, \& Hausken, 1995), researchers have demonstrated that children spend very little time in any of these activities (Goldscheider \& Waite, 1991; Medrich, Roizen, Rubin, \& Buckley, 1982).

Mealtime, when parents and children gather as a family to share their daily experiences, has been little discussed in the literature but is likely to be an important correlate of children's well-being. Time spent in meals at home is likely to be associated with a more stable, organized family life and therefore with children having fewer behavior problems. Finally, sleep routines and sleep time are important components of individual and family time and should be associated with child development.

\section{Factors Associated With DifFERENCES IN TIME UsE}

Children's time is likely to be affected, first and foremost, by their age. From a developmental perspective, systematic changes in children's activities - a decline in sleeping, eating, and playing and an increase in school and other structured activities-occur as they grow and mature (Robinson \& Bianchi, 1997). Although less pronounced among young children, gender differences in activities begin to appear in elementary school. Variation in use of time is also likely to be associated with the employment status of the mother, parental education and income, the number and age of parents, family size, and race and ethnicity.

As mothers spend more time in the workforce, children's activities change. Compared with children of nonemployed mothers, children with employed mothers spend more time in day care. This includes preschool programs or family childcare for young children and before- and after-school programs for school-age children. With more time away, the time women spend doing household work has declined significantly over the past several decades (Gershuny \& Robinson, 1988); children's household work may also decline. Because the lives of young children depend on the tightly scheduled lives of their working parents, we may see more structured activities at the expense of unstructured activities. Maternal employment time may increase at the expense of informal family and personal activities, such as eating meals and sleeping, or discretionary activities, such as church attendance and visiting. The time spent reading with children or helping them complete homework may also decline, although research in a California sample failed to find such an association (Bianchi \& Robinson, 1997).

Education reflects preferences for academic skills, and higher income may facilitate spending on books. We expect that the children of better educated and higher income parents will spend more time reading and studying. Bianchi and Robinson (1997) found that children spent more time reading or being read to in households with moreeducated than less-educated parents. The same authors found an inverse relationship between television viewing time and parental education but no significant relationship with income.

Children living with single parents tend to take on family responsibilities at younger ages than do children living with two parents (Longfellow, 1979); consequently, we expect them to participate more in household chores. We expect the time spent in day-care programs to increase as well because a single parent cannot rely on another parent for day care, and we expect these children to spend less time playing at home. Television watching, used as an inexpensive babysitter, may increase. Children of single working parents may exhibit lower participation in secular and religious organizational activities. Previous research failed to find a relationship between the number of parents and 3- to 11-year-old children's reading, studying, or television time (Bianchi \& Robinson, 1997), nor did it find any association between the number of parents and the time children spent in household work. But previous research did not take into account the joint influence of the number and employment of parents as we do here.

Small family size may have positive or negative effects. In smaller families, parents may increase the time spent in educational and leisure activities (Blake, 1989). Having fewer children also means that siblings are less available for play and help with homework (Zajonc \& Markus, 1975). Research has found that children in large families spend more time in household work than do children in small families (Bianchi \& Robinson, 1997).

Cultural differences reflected in family race and ethnicity may also affect children's activity time. With their greater emphasis on familism, Hispanic families may involve their children in household chores (Taylor, 1994); with their greater concern for academic success, Asian families may promote more studying (Kao, Tienda, \& Schneider, 1996) than majority families. Black and older parent families may encourage involvement in church activities (Taylor \& Chatters, 1988). 


\section{IMPLICATIONS OF TIME FOR CHILD DEVELOPMENT}

Because daily time must add up to 24 hours, spending time on some activities means less time on others. It is important to know the relative benefit to children's cognitive and emotional development of an additional hour spent reading, for example, versus an additional hour spent watching television. Based on the literature, we expect time spent reading and studying to be linked to verbal achievement, and time spent watching television to be associated with poorer verbal scores. There is less guidance from the literature on the effects of time expenditures on children's socioemotional behavior. Family and social activities, such as going to church, eating meals, and visiting with others, are expected to be related to fewer behavior problems because those activities provide social support. Participation in structured activities such as sports is also likely to be associated with fewer behavior problems, both because children who are aggressive or withdrawn are not likely to participate and because such activities are likely to improve children's self-esteem through the development of physical and social skills.

\section{DATA AND METHOD}

\section{The Child Development Supplement to the Panel Study of Income Dynamics}

The study sample was drawn from the 1997 Child Development Supplement (CDS) to the Panel Study of Income Dynamics (PSID), a 30-year longitudinal survey of a representative sample of U.S. men, women, children, and the families in which they reside. In 1997, the PSID added a refresher sample of immigrants to the United States so that the sample represents the U.S. population in 1997. When weights are used, the PSID has been found to be representative of U.S. individuals and their families (Fitzgerald, Gottschalk, \& Moffitt, 1998).

With funding from the National Institute of Child Health and Human Development (NICHD), data were collected in 1997 on up to two randomly selected 0- to 12-year-old children of PSID respondents, both from the primary caregivers and from the children themselves. The CDS survey period began in March 1997 and ended in December 1997 with a break from mid-June through $\mathrm{Au}-$ gust; thus, the study took place only during the school year. Interviews were completed with
2,380 child households containing 3,563 children. The response rate was $88 \%$. Poststratification weights based upon the 1997 Current Population Survey were used to make the data nationally representative. Sample characteristics reflect the characteristics of the population of children under age 13 in the United States in 1997.

\section{Time Diaries}

Most surveys obtain estimates of time expenditures by asking parents directly how much time they spend in certain activities, such as reading to their child. Although simple and widely used, this method is subject to social desirability bias. Parents report more time spent on desirable activities (such as reading to a child) than on less desirable ones (Hofferth, 1999). Second, the validity of the answers is poor when activities are infrequent (Juster \& Stafford, 1985; Marini \& Shelton, 1993). In contrast, substantial methodological work has established the validity and reliability of data collected in time-diary form (Juster \& Stafford). For example, estimates of elementary school age children's time spent in television viewing range from 13 (Bianchi \& Robinson, 1997; Timmer et al., 1985) to 30 hours per week (Medrich et al., 1982). Most studies using diaries have estimated television time to average 13 to 15 hours per week. Studies obtaining higher figures may include time in which the television may be on but it is not the primary activity. The single study that compared parent reports with timelapse video home observation reported that 5year-old children watched an average of 14.2 hours according to diaries compared with 13.4 actually observed hours (Anderson, Field, Collins, Lorch, \& Nathan, 1985). This supports our contention that diaries produce reasonably accurate estimates of frequent activities.

The 1997 CDS collected a complete time diary for one weekday and one weekend day for $79 \%$ $(2,818)$ of the 3,563 sample children aged 0 to 12 . Comparisons between children who provided a diary and those who did not showed no significant differences on demographic characteristics. The time diary, which was interviewer-administered either to the parent or to the parent and child, asked questions about the child's flow of activities over a 24-hour period beginning at midnight of the randomly designated day. These questions ask the primary activity that was going on at that time, when it began and ended, and whether any other activity was taking place simultaneously. Chil- 
dren's activities were first assigned to 1 of 10 general activity categories (e.g., sports and active leisure) and then coded into 3-digit subcategories (e.g., playing soccer). Coding was conducted by professional coders employed by the data collection organization; the level of reliability exceeded $90 \%$. For this study, the primary activities of children aged 3 to 11 were classified into the 18 major categories used by Timmer and colleagues (1985) plus day care. Time spent traveling for the purposes of engaging in a specific activity is included in that category. Secondary activities, such as having the television on while doing homework, are not counted as "watching television." Thus, some activities that are often secondary may appear underestimated. Weekly time is computed by multiplying weekday time by 5 and weekend day time by 2 , after removing children who do not have both a weekend and weekday diary and two who spent the week visiting. Although the first analyses include all 2,818 children under 12 , for the regression analyses we included only the 2,151 children aged 3 through 12 because test scores are only available for these children. A few cases were missing demographic variables; their omission reduced the analysis sample for the regressions with controls to 2,123 cases. The actual number of cases varies by outcome; not all children were assessed. Furthermore, only children aged 6 and older were administered the Passage Comprehension and Calculation tests.

\section{Measurement of the Demographic Variables}

The demographic variables used to analyze the impact of family factors on the time of children 3 to 12 include age and gender of child; age and race of head of household; family type and employment of head and spouse; family income; education of head; and number of children. Age of child, age of head, education of head (years of completed schooling), income, and number of children in the family are continuous variables with means of $7.5,38,13, \$ 51,200$, and 2.5 , respectively. To make the coefficients comparable, income is scaled in tens of thousands of dollars. Race and ethnicity is categorical-68\% are nonHispanic White, 16\% non-Hispanic Black, 11\% Hispanic, 3\% Asian, and 2\% other races. NonHispanic White is the omitted comparison category. Gender is dichotomous, with 0 indicating male and 1 indicating female; $49 \%$ were female respondents. An interaction between gender and age is included to capture gender differences in activities with age. Finally, to capture the joint effect of employment and family structure, we included six dummy variables-dual-earner family (44\%), female breadwinner-male nonemployed family (3\%), no breadwinner family (4\%), single employed female-headed family (15\%), single nonemployed female-headed family $(6 \%)$, and single male-headed family $(3 \%)$, with the male breadwinner-female homemaker family $(25 \%)$ the omitted, comparison category.

\section{Child Assessments}

This article examines the association between children's activities and their achievement measured by standardized tests, controlling for the demographic variables associated with activity choice. Four subtests of the Woodcock-Johnson Revised Test of Basic Achievement were used: letter-word identification, a test of children's ability to identify and respond to letters and words; passage comprehension, a test that measures vocabulary and comprehension skills; calculation, a test of mathematical calculation performance; and applied problems, a test of skill in analyzing and solving practical numerical problems (Woodcock \& Mather, 1989). Scores are age-standardized with a mean of 100 and a standard deviation of 15. In addition, children's socioemotional adjustment is measured by the Behavior Problems Index. The Behavior Problems Index, developed by Peterson and Zill obtains parent reports of the incidence and severity of child behavior problems in a survey setting (Peterson \& Zill, 1986). The 30 -item scale is divided into two subscales, one measuring withdrawn or distressed behavior, called "internalizing," and the other measuring aggressive behavior, called "externalizing." Means for the full scale average 40, with a standard deviation of 8 . Reliabilities for the total, internal, and external scales, as measured by Cronbach's alpha, are $0.90,0.81$, and 0.86 .

\section{RESULTS}

\section{Number of Activities}

The results presented first are based on the 2,818 children between birth and age 12 whose parents had completed time diaries for them (or with them) for 2 days in the previous week. Children were reported to have, on average, 22 to 24 activities on a weekday and 24 on a weekend (analyses not shown). The mean number of different activ- 
Table 1. Percentage of Children Engaging in Major Activities and Weekly Hours: Minutes Spent by All ChildRen, By AGE, 1997

\begin{tabular}{|c|c|c|c|c|c|c|c|c|c|c|}
\hline \multirow[b]{2}{*}{ Variable } & \multicolumn{2}{|c|}{$\begin{array}{l}0 \text { to } 2 \text { Years } \\
(N=667)\end{array}$} & \multicolumn{2}{|c|}{$\begin{array}{c}3 \text { to } 5 \text { Years } \\
(N=629)\end{array}$} & \multicolumn{2}{|c|}{$\begin{array}{l}6 \text { to } 8 \text { Years } \\
(N=639)\end{array}$} & \multicolumn{2}{|c|}{$\begin{array}{l}9 \text { to } 12 \text { Years } \\
(N=883)\end{array}$} & \multicolumn{2}{|c|}{$\begin{array}{c}\text { Total } \\
(N=2,818)\end{array}$} \\
\hline & $\%$ & Hours: Min & $\%$ & Hours: Min & $\%$ & Hours: Min & $\%$ & Hours: Min & $\%$ & Hours: Min \\
\hline Market work & 1 & 0:00 & 0 & $0: 00$ & 2 & $0: 06$ & 4 & $0: 16$ & 2 & 0:07 \\
\hline Household work & 68 & $4: 40$ & 81 & $6: 09$ & 80 & $4: 45$ & 88 & $6: 09$ & 80 & $5: 29$ \\
\hline Personal care & 99 & $8: 55$ & 100 & $8: 32$ & 100 & $7: 56$ & 100 & $7: 57$ & 100 & $8: 18$ \\
\hline Eating & 100 & $11: 38$ & 100 & $9: 22$ & 100 & $8: 08$ & 100 & $7: 25$ & 100 & 9:01 \\
\hline Sleeping & 100 & $86: 01$ & 100 & $76: 08$ & 100 & $70: 34$ & 100 & $67: 39$ & 100 & $74: 33$ \\
\hline School & 15 & $1: 33$ & 52 & $12: 05$ & 91 & $32: 18$ & 90 & $33: 37$ & 64 & $20: 55$ \\
\hline Studying & 4 & $0: 12$ & 17 & $0: 34$ & 55 & 2:09 & 62 & $3: 40$ & 36 & $1: 48$ \\
\hline Church & 12 & $0: 27$ & 24 & $1: 03$ & 25 & $1: 20$ & 28 & $1: 30$ & 23 & $1: 07$ \\
\hline Visiting & 48 & $2: 40$ & 59 & $3: 21$ & 61 & $3: 28$ & 69 & $3: 28$ & 60 & $3: 15$ \\
\hline Sports & 56 & $2: 13$ & 73 & $4: 10$ & 76 & $5: 17$ & 76 & $6: 26$ & 70 & $4: 40$ \\
\hline Outdoors & 9 & $0: 25$ & 19 & $0: 37$ & 14 & $0: 29$ & 17 & $0: 42$ & 15 & $0: 34$ \\
\hline Hobbies & 2 & 0:01 & 2 & $0: 05$ & 2 & $0: 04$ & 4 & 0:09 & 2 & $0: 05$ \\
\hline Art activities & 19 & $0: 31$ & 36 & $1: 15$ & 23 & $0: 44$ & 22 & $0: 56$ & 25 & $0: 51$ \\
\hline Playing & 100 & $24: 55$ & 98 & $17: 26$ & 92 & $11: 55$ & 88 & $8: 50$ & 94 & $15: 16$ \\
\hline Television & 71 & $7: 47$ & 98 & $13: 49$ & 96 & $12: 47$ & 94 & $13: 33$ & 90 & $12: 04$ \\
\hline Reading & 42 & $1: 15$ & 53 & $1: 26$ & 43 & 1:09 & 34 & $1: 15$ & 42 & $1: 16$ \\
\hline Household conversations & 41 & $1: 11$ & 38 & 0.49 & 31 & $0: 30$ & 28 & $0: 27$ & 34 & $0: 43$ \\
\hline Other passive leisure & 53 & $2: 49$ & 54 & $2: 37$ & 46 & $1: 33$ & 52 & $2: 22$ & 51 & $2: 21$ \\
\hline Day care & 25 & $9: 20$ & 23 & $7: 27$ & 13 & $1: 42$ & 4 & 0.26 & 16 & 4.24 \\
\hline Total & & $166: 36$ & & $166: 55$ & & $166: 54$ & & $166: 45$ & & $166: 47$ \\
\hline N/A & & $1: 25$ & & $1: 05$ & & 1:06 & & $1: 15$ & & $1: 13$ \\
\hline $\begin{array}{l}\text { Percent of time accounted } \\
\text { for by activities }\end{array}$ & & $99.2 \%$ & & $99.4 \%$ & & $99.3 \%$ & & $99.3 \%$ & & $99.3 \%$ \\
\hline
\end{tabular}

Note: Total weekly time in hours: minutes $=168: 00$. Weekly times for individuals derived as the sum of 5 times weekday time +2 times weekend day time.

ities, the "variety of activities," was 11 to 13 on both weekday and weekend days. These estimates are similar to estimates obtained in earlier research (Timmer et al., 1985).

\section{Participation and Time Spent in Activities}

Table 1 lists the age of children engaging in each of 19 primary activities in a week, by age, estimated from their time diaries. From this table, it is clear that all children in the sample sleep, eat, and engage in or receive personal care and that most play and watch television. Few engage in market work or hobbies. Otherwise, the types of activities vary by age of the child. For example, although few preschool age children study, more than half of school-age children do so. Given that many activities are occasional, we would not expect all children to engage in most of these on a daily or weekly basis. Nonetheless, we wanted to abstract from the reports of a representative sample of children's weeks to describe the activities of American children. To do so, we calculated the average time all children spend in an activity, which was a function of the proportion of those who engage in the activity and the time those participating spend in it. Time estimates based on activities with low frequencies, such as hobbies and market work, were likely to be unreliable estimates of the overall allocation of time and are not discussed here.

Table 1 also shows the average hours and minutes children under age 13 spent in 19 activities in an average week in 1997. The bottom row shows that $99 \%$ of the 24-hour period was accounted for, an indicator of the comprehensiveness of our coding categories. We first focus on children's nondiscretionary time; that is, time spent in school and day care.

Children's time in school. American children spent about 21 hours per week in school and another 4 hours and 24 minutes in day care in 1997. As one would expect, time spent in school varies dramatically by age. Children under age 3 spent almost no time in school. Children age 3 to 5 spent 12 hours in school, whereas children aged 6 to 8 and 9 to 12 spent 32 to 33 hours in school per week. These estimates are consistent with earlier research (Timmer et al., 1985), although high- 
er than studies that conducted interviews during the summer months (Robinson \& Bianchi, 1997) or that excluded classroom time not devoted to schoolwork (Larson \& Verma, 1999). Our estimates included travel time to and from school, which averages about 2 hours per week (not shown). Children under age 3 spent more than 9 hours per week in day care, children aged 3 to 5 about $7 \frac{1}{2}$ hours, children aged 6 to 8 about $13 / 4$ hours, and children aged 9 to 12 about $1 / 2$ hour per week in day care. These estimates were averaged over all children, including those who spent no time in the activity.

Discretionary time: children's free play versus structured activities. To obtain the amount of free time children had in 1997, we subtracted nondiscretionary time-time spent in personal care, eating, sleeping, and school (including day care)from 168 hours. That amounted to 51 hours or $30 \%$ of children's week. About half of this free time was spent in unstructured play (15 hours) or television watching (12 hours). About half an hour was spent in outdoor activities. In contrast, 43/4 hours were spent in sports, 1 hour was spent in church, and 3 hours were spent visiting. Assuming that the latter represent structured activities, the total adds to only $83 / 4$ hours per week, less than one fifth of their free time.

The proportion of children's time spent in structured activities (sports, visiting, church) increased as children aged, from $5 \frac{1}{2}$ hours among 0- to 2-year-olds to $11 \frac{1}{2}$ hours among 9- to 12 year-olds. Concomitantly, the amount of time spent playing declined to less than 9 hours $(18 \%$ of time) among older elementary school age children from almost 25 hours among infants and toddlers. The time per week spent watching television almost doubled to $13 \frac{1}{2} 2$ hours from $73 / 4$ hours. Thus, the amount of structured time was larger among older than younger children, although it was still only about $22 \%$ of their discretionary time.

The time children spent in other passive leisure amounted to only 2 hours per week. Besides going to movies and sports events at which children were spectators, passive leisure includes listening to music and just sitting around. Age variation was small for this category.

Out-of-school learning time. Children spent about $13 / 4$ hours studying, but there was substantial variation by age. As can be expected, preschool-age children spent little time "studying." Children aged 6 to 8 spent about 2 hours and 9 minutes studying, about 26 minutes per school day. Children 9 to 12 spent about 3 hours 40 minutes studying, 44 minutes per school day. In contrast, children spent about 1 hour per week reading for pleasure, with little variation in reading time among children of different ages. At young ages, parents read to children; at older ages, children read to themselves.

Television time can be considered learning or passive leisure, depending on what children are watching. Children watched about 12 hours per week during 1997, representing $1 / 4$ of their free time. Television viewing increased as children age, from about $73 / 4$ hours for very young children to $13 \frac{1}{2}$ hours among 9- to 12 -year-olds. After children reach age 3 , television viewing remained stable at approximately 13 hours per week, slightly less than 2 hours per day.

Family time. Time in household work amounted to $5 \frac{1}{2}$ hours per week in 1997 . A substantial component of household work was shopping. Children tended to accompany their parents in this activity, which explains the high amount of time among young children. Time spent eating meals amounted to about 9 hours per week in 1997, about 1 hour and 15 minutes per day. Children averaged about three-quarters of an hour in conversation as a primary activity.

The largest component of children's time was sleeping, at 74 hours and 33 minutes per week in 1997 , or about $10 \frac{1}{2}$ hours per night. Sleeping declined from 12 hours per day for infants and toddlers to 10 hours for older elementary school children. Personal care occupied about 8 hours.

\section{Family Characteristics and Children's Time}

For the multivariate analysis, children 3 to 12 in 1997 were subselected from the full sample, to which their other characteristics were similar. In Table 2, we present the coefficients for the impact of family factors on weekly time spent in school, day care, play, housework, reading, studying, sports, television, church, visiting, and sleeping using Tobit regression models. These models adjust for the fact that not all children engaged in each activity (Tobin, 1958). If this technique were not used, the regression slope would be biased by the inclusion of zero values. The coefficients reflect both the effect of the independent variable on the probability of the activity and on the hours spent in the activity by participants (McDonald \& 
Table 2. Parameter Estimates of Tobit Equations for the Hours per Week Children Aged 3-12 Spent in TYPICAL ACTIVITIES

\begin{tabular}{|c|c|c|c|c|c|}
\hline Variable & School & Day Care & Play & Church & Sports \\
\hline Intercept & $\begin{array}{r}-5.64 \\
(3.28)\end{array}$ & $\begin{array}{l}-0.82 \\
(11.36)\end{array}$ & $\begin{array}{c}23.25 * \\
(1.77)\end{array}$ & $\begin{array}{r}-11.47 * \\
(2.00)\end{array}$ & $\begin{array}{c}0.54 \\
(1.51)\end{array}$ \\
\hline Age of child & $\begin{array}{c}3.71 * \\
(0.20)\end{array}$ & $\begin{array}{c}-7.48 * \\
(0.78)\end{array}$ & $\begin{array}{c}-1.19 * \\
(0.11)\end{array}$ & $\begin{array}{c}0.14 \\
(0.12)\end{array}$ & $\begin{array}{r}0.70 * \\
(0.09)\end{array}$ \\
\hline Age of head & $\begin{array}{c}0.02 \\
(0.05)\end{array}$ & $\begin{array}{r}-0.11 \\
(0.19)\end{array}$ & $\begin{array}{r}-0.04 \\
(0.03)\end{array}$ & $\begin{array}{c}0.11 * \\
(0.03)\end{array}$ & $\begin{array}{r}-0.01 \\
(0.02)\end{array}$ \\
\hline Black & $\begin{array}{c}3.66^{*} \\
(1.21)\end{array}$ & $\begin{array}{c}0.28 \\
(3.81)\end{array}$ & $\begin{array}{c}-3.46 * \\
(0.67)\end{array}$ & $\begin{array}{c}3.29 * \\
(0.74)\end{array}$ & $\begin{array}{r}-3.56^{*} \\
(0.57)\end{array}$ \\
\hline Hispanic & $\begin{array}{c}0.66 \\
(1.43)\end{array}$ & $\begin{array}{r}-7.97 \\
(5.75)\end{array}$ & $\begin{array}{c}-2.63^{*} \\
(0.78)\end{array}$ & $\begin{array}{r}-0.09 \\
(0.88)\end{array}$ & $\begin{array}{r}-4.23^{*} \\
(0.68)\end{array}$ \\
\hline Asian & $\begin{array}{c}2.30 \\
(2.48)\end{array}$ & $\begin{array}{r}-14.39 \\
(11.44)\end{array}$ & $\begin{array}{c}-3.27 * \\
(1.34)\end{array}$ & $\begin{array}{r}-0.54 \\
(1.55)\end{array}$ & $\begin{array}{r}-4.37 \\
(1.18)\end{array}$ \\
\hline Other race & $\begin{array}{c}5.41 \\
(3.04)\end{array}$ & $\begin{array}{r}-18.55 \\
(12.33)\end{array}$ & $\begin{array}{c}-3.62 * \\
(1.68)\end{array}$ & $\begin{array}{r}-1.61 \\
(2.01)\end{array}$ & $\begin{array}{r}-4.68 \\
(1.47)\end{array}$ \\
\hline Two earner & $\begin{array}{c}1.71 \\
(1.00)\end{array}$ & $\begin{array}{c}32.04^{*} \\
(4.35)\end{array}$ & $\begin{array}{r}-2.26^{*} \\
(0.54)\end{array}$ & $\begin{array}{r}-1.01 \\
(0.58)\end{array}$ & $\begin{array}{c}0.36 \\
(0.46)\end{array}$ \\
\hline Female breadwinner & $\begin{array}{c}1.34 \\
(2.46)\end{array}$ & $\begin{array}{c}32.11 * \\
(8.55)\end{array}$ & $\begin{array}{r}-2.08 \\
(1.35)\end{array}$ & $\begin{array}{r}-1.54 \\
(1.45)\end{array}$ & $\begin{array}{r}-1.97 \\
(1.16)\end{array}$ \\
\hline No breadwinner & $\begin{array}{c}0.56 \\
(2.20)\end{array}$ & $\begin{array}{l}-1.66 \\
(12.61)\end{array}$ & $\begin{array}{c}0.79 \\
(1.19)\end{array}$ & $\begin{array}{c}-5.45 * \\
(1.53)\end{array}$ & $\begin{array}{c}1.40 \\
(1.04)\end{array}$ \\
\hline Working female head & $\begin{array}{c}2.44 \\
(1.37)\end{array}$ & $\begin{array}{c}41.35^{*} \\
(5.20)\end{array}$ & $\begin{array}{c}-3.32 * \\
(0.75)\end{array}$ & $\begin{array}{c}-5.25^{*} \\
(0.92)\end{array}$ & $\begin{array}{c}0.58 \\
(0.64)\end{array}$ \\
\hline Nonworking female head & $\begin{array}{r}-1.07 \\
(1.89)\end{array}$ & $\begin{array}{c}3.46 \\
(7.56)\end{array}$ & $\begin{array}{c}0.94 \\
(1.02)\end{array}$ & $\begin{array}{c}-3.63^{*} \\
(1.18)\end{array}$ & $\begin{array}{r}2.53 \\
(0.87)\end{array}$ \\
\hline Male head & $\begin{array}{c}3.20 \\
(2.24)\end{array}$ & $\begin{array}{c}32.34 * \\
(7.83)\end{array}$ & $\begin{array}{r}-0.03 \\
(1.23)\end{array}$ & $\begin{array}{r}-2.18 \\
(1.42)\end{array}$ & $\begin{array}{r}-0.66 \\
(1.04)\end{array}$ \\
\hline Gender of child $(1=F)$ & $\begin{array}{c}3.42 \\
(2.23)\end{array}$ & $\begin{array}{r}-14.03^{*} \\
(6.85)\end{array}$ & $\begin{array}{c}0.79 \\
(1.18)\end{array}$ & $\begin{array}{c}1.15 \\
(1.32)\end{array}$ & $\begin{array}{r}-0.54 \\
(1.01)\end{array}$ \\
\hline Gender*age & $\begin{array}{r}-0.55^{*} \\
(0.27)\end{array}$ & $\begin{array}{c}1.66 \\
(1.01)\end{array}$ & $\begin{array}{r}-0.28 \\
(0.15)\end{array}$ & $\begin{array}{r}-0.15 \\
(0.16)\end{array}$ & $\begin{array}{r}-0.53^{*} \\
(0.12)\end{array}$ \\
\hline Income $(0000)$ & $\begin{array}{c}0.04 \\
(0.08)\end{array}$ & $\begin{array}{c}0.57 * \\
(0.22)\end{array}$ & $\begin{array}{r}-0.01 \\
(0.05)\end{array}$ & $\begin{array}{c}0.04 \\
(0.04)\end{array}$ & $\begin{array}{r}-0.03 \\
(0.04)\end{array}$ \\
\hline Education of head & $\begin{array}{r}-0.12 \\
(0.16)\end{array}$ & $\begin{array}{c}0.17 \\
(0.61)\end{array}$ & $\begin{array}{c}0.09 \\
(0.09)\end{array}$ & $\begin{array}{c}0.12 \\
(0.09)\end{array}$ & $\begin{array}{c}0.08 \\
(0.07)\end{array}$ \\
\hline Number of children & $\begin{array}{c}0.74 * \\
(0.37)\end{array}$ & $\begin{array}{r}-5.68 * \\
(1.47)\end{array}$ & $\begin{array}{c}0.47 * \\
(0.20)\end{array}$ & $\begin{array}{c}0.13 \\
(0.22)\end{array}$ & $\begin{array}{c}0.20 \\
(0.18)\end{array}$ \\
\hline Scale & $\begin{array}{c}17.23 \\
(0.32)\end{array}$ & $\begin{array}{c}34.59 \\
(1.77)\end{array}$ & $\begin{array}{c}9.53 \\
(0.16)\end{array}$ & $\begin{array}{c}8.23 \\
(0.29)\end{array}$ & $\begin{array}{c}7.88 \\
(0.15)\end{array}$ \\
\hline Log likelihood & $-7,643$ & $-1,714$ & $-7,331$ & $-2,594$ & $-5,983$ \\
\hline $\mathrm{N}$ (noncensored) & 1,682 & 295 & 1,903 & 587 & 1,564 \\
\hline $\mathrm{N}$ (censored) & 441 & 1,828 & 220 & 1,536 & 559 \\
\hline
\end{tabular}

Note: Standard errors in parentheses.

$* p<.05$.

Moffitt, 1980). The higher the proportion of children who participate in the activity, the more the results reflect the hours among participants and thus the more similar the results become to those from ordinary least squares regressions just on participants. We discuss the activities according to the four issues described earlier-school and daycare time, unstructured versus structured activities, out-of-school learning, and family time.

School or day care. As expected, enrollment in day care (but not in school) is linked to the age of the child and the employment status of mothers.
As they aged, children spent more time in school and less in day care. Children of employed mothers, regardless of whether the mother was married or single, were more likely to be in day care and spent more time there than children in a male breadwinner-female homemaker family, the omitted category. Children from higher income families spent more time in day care, but not in school, probably because of their greater ability to afford private programs. Net of income and parental education, Black children spent more time in school. This may reflect a difference in school scheduling patterns in schools with minority populations or 
TABLE 2. EXTENDED

\begin{tabular}{|c|c|c|c|c|c|c|}
\hline Visiting & Housework & Eating & Sleep & Reading & Studying & TV \\
\hline $4.26 *$ & 1.88 & $8.49 *$ & $79.37^{*}$ & $-3.11 *$ & $-12.92 *$ & $18.58 *$ \\
\hline$(1.60)$ & $(1.27)$ & $(0.62)$ & (1.47) & $(0.90)$ & (1.31) & (1.80) \\
\hline-0.11 & -0.01 & $-0.24 *$ & $-1.04 *$ & $-0.35^{*}$ & $1.05^{*}$ & -0.06 \\
\hline$(0.10)$ & $(0.08)$ & $(0.04)$ & $(0.09)$ & $(0.06)$ & $(0.08)$ & (0.11) \\
\hline-0.05 & 0.02 & $0.02 *$ & -0.01 & 0.02 & $0.06^{*}$ & 0.04 \\
\hline$(0.03)$ & $(0.02)$ & $(0.01)$ & $(0.02)$ & $(0.02)$ & $(0.02)$ & $(0.03)$ \\
\hline-0.55 & $-1.85^{*}$ & $0.55^{*}$ & $-1.08 *$ & $-1.29 *$ & $1.85^{*}$ & $2.63 *$ \\
\hline$(0.61)$ & $(0.48)$ & $(0.23)$ & $(0.55)$ & $(0.36)$ & $(0.46)$ & $(0.68)$ \\
\hline$-1.73 *$ & $2.59 *$ & $1.02 *$ & 1.02 & $-0.89 *$ & $3.23 *$ & -0.00 \\
\hline$(0.72)$ & $(0.56)$ & $(0.27)$ & $(0.65)$ & $(0.42)$ & $(0.53)$ & $(0.80)$ \\
\hline-1.36 & -1.63 & 0.32 & 1.43 & $1.48 *$ & $2.46^{*}$ & $4.77 *$ \\
\hline$(1.25)$ & $(0.96)$ & $(0.47)$ & (1.12) & $(0.64)$ & $(0.91)$ & (1.37) \\
\hline $3.25 *$ & -0.03 & 0.36 & 0.87 & 0.33 & 1.40 & -2.47 \\
\hline (1.46) & $(1.20)$ & $(0.58)$ & $(1.38)$ & $(0.82)$ & (1.19) & (1.70) \\
\hline 0.08 & 0.09 & -0.37 & $-1.04 *$ & $-0.52 *$ & -0.70 & $-1.17^{*}$ \\
\hline (0.49) & (0.39) & $(0.19)$ & $(0.45)$ & $(0.26)$ & $(0.38)$ & $(0.56)$ \\
\hline 1.57 & -1.45 & -0.51 & -0.05 & $-1.55 *$ & -0.53 & -0.20 \\
\hline$(1.22)$ & (0.98) & $(0.47)$ & (1.12) & $(0.72)$ & (0.94) & (1.37) \\
\hline-1.42 & -0.24 & $-1.28 *$ & $2.73^{*}$ & $-1.24 *$ & $-3.13 *$ & -1.62 \\
\hline (1.12) & $(0.87)$ & $(0.42)$ & $(0.99)$ & $(0.63)$ & $(0.88)$ & (1.23) \\
\hline$-1.46^{*}$ & -0.47 & $-0.99 *$ & $-1.53 *$ & $-2.09 *$ & -0.52 & 0.05 \\
\hline$(0.69)$ & $(0.54)$ & $(0.26)$ & $(0.62)$ & $(0.40)$ & $(0.52)$ & $(0.77)$ \\
\hline-0.57 & -1.45 & 0.21 & -0.07 & $-1.52 *$ & -1.04 & -0.68 \\
\hline$(0.95)$ & $(0.75)$ & $(0.36)$ & $(0.85)$ & $(0.56)$ & $(0.72)$ & (1.05) \\
\hline-0.23 & -0.27 & $-0.88 *$ & -1.17 & -0.66 & -1.34 & -0.86 \\
\hline (1.12) & $(0.88)$ & $(0.43)$ & (1.02) & $(0.62)$ & $(0.84)$ & (1.26) \\
\hline$-4.77 *$ & 1.15 & $0.87 *$ & $3.95^{*}$ & $-1.62 *$ & 0.65 & -0.97 \\
\hline (1.08) & $(0.85)$ & $(0.41)$ & $(0.98)$ & $(0.58)$ & (0.92) & (1.20) \\
\hline $0.67 *$ & 0.08 & $-0.11 *$ & $-0.41 *$ & $0.29 *$ & -0.15 & 0.17 \\
\hline$(0.13)$ & $(0.10)$ & $(0.05)$ & $(0.12)$ & $(0.07)$ & $(0.11)$ & $(0.15)$ \\
\hline-0.00 & -0.05 & $0.03 *$ & -0.04 & -0.00 & 0.02 & $-0.09 *$ \\
\hline$(0.04)$ & $(0.03)$ & $(0.02)$ & $(0.04)$ & $(0.02)$ & $(0.03)$ & $(0.05)$ \\
\hline 0.06 & $0.18^{*}$ & 0.04 & 0.02 & $0.36 *$ & $0.18 *$ & $-0.46^{*}$ \\
\hline$(0.08)$ & $(0.06)$ & (0.03) & $(0.07)$ & $(0.05)$ & $(0.06)$ & (0.09) \\
\hline-0.36 & -0.12 & 0.02 & 0.04 & -0.10 & -0.10 & -0.06 \\
\hline (0.19) & $(0.15)$ & $(0.07)$ & $(0.17)$ & $(0.11)$ & $(0.14)$ & $(0.21)$ \\
\hline 8.15 & 6.74 & 3.36 & 7.98 & 4.15 & 5.84 & 9.78 \\
\hline$(0.17)$ & $(0.12)$ & $(0.05)$ & $(0.12)$ & (0.11) & (0.14) & (0.16) \\
\hline$-5,308$ & $-6,220$ & $-5,573$ & $-7,407$ & $-3,193$ & $-3,799$ & $-7,607$ \\
\hline 1,332 & 1,696 & 2,118 & 2,123 & 807 & 1,020 & 2,043 \\
\hline 791 & 427 & 5 & 0 & 1,316 & 1,103 & 80 \\
\hline
\end{tabular}

differential use of school-based after-school programs.

Free play versus structured activities. Due to maternal responsibility for caring for children and, therefore, the increased time such children spend out of the home, free play time at home was lower when mothers were employed than when they were not. Consistent with expectations, as children grow older, they spend less time playing and more time in other activities. Interestingly, the time spent playing declined marginally faster by age for girls than for boys. Girls' time in activities such as reading and visiting increased faster than that for boys, whereas boys' time increased faster in sports. Net of other factors, Black, Hispanic, and Asian children spent less time playing than White non-Hispanic children. Children in large families spent more time playing, most likely with each other. The head's education and family income were not related to children's play time.

Compared with children in male breadwinnerfemale homemaker families, children in all other family types spent less time in church. Given traditional church teachings with regard to divorce and nonmarital childbearing, we suspect that families that do not fit prevalent lifestyle and parenting norms were simply less likely to attend reg- 
ularly. Although busy schedules are part of the story, it is not simply a matter of having a busy schedule because children in families with no breadwinner or with a nonemployed female head also spent less time in church. As expected, children from Black families and families with an older head spent more time in church. Church time offset the lower play time of Black children.

Family type is important to sports participation. Children of nonworking female heads spent more time in sports than did children living in a male breadwinner-female homemaker family. Perhaps such parents utilize sports programs as a source of supervision for their children, whereas children of employed female heads utilize formal child-care programs. As children aged, they spent more time in sports activities. Although there was no significant overall gender difference in sports participation at younger ages, as they aged, girls' participation declined relative to that of boys, reflecting an increasing gender gap. Despite the fact that sports is an avenue for skill-building and upward mobility, minority children spent less time in sports than did White children, all else equal. This may reflect differential access to such programs. Children in large families spent more time in sports, perhaps due to exposure through older siblings. Neither parental education nor income was associated with participation of children in sports activities, net of other factors.

The time spent socializing and participating in privately sponsored clubs and programs was also linked to family structure and employment. Children from families with a working female head were less likely to participate in such activities than were children in a male breadwinner-female homemaker family, probably because they were too busy. Girls spent significantly less time at young ages visiting than boys; however, as they grow older, girls' time in such activities increases faster than boys' time. Children in larger families spent marginally less time visiting than did those in smaller families, perhaps because of the greater opportunity for social activities within the family. There were no differences in visiting by family income or education.

Family time. In contrast to expectations, no differences in children's household work time by family structure and maternal employment were found. Children did not help more or less in household chores if their mother was employed. Consistent with greater familism, children in Hispanic families spent more time in household work than did children in White non-Hispanic families, whereas children in Black and Asian families spent less time. For Hispanic children, the greater amount of household work offset the lower amount of time spent playing. There are no gender differences in time spent in household work; these children were still rather young. Finally, in families with a better educated head, children do more housework. This may be due to greater expectations for children in such families or to more time spent shopping.

Although maternal employment is associated with reduced time children spend eating, the income it brings permits more time eating. Cultural differences in eating patterns may be reflected in the finding that children from Black and Hispanic families spent more time eating than did children from White families. As children aged, they spent less time eating and more time in other activities. Children living with older parents also spent more time eating meals.

Maternal employment was linked to sleep. Children in dual-earner families and children in families with a working female head spent less time sleeping than did children in male breadwinner-female homemaker families. If there was no breadwinner, children got more sleep. Sleep depended on children's characteristics, of course. As expected, older children slept less than younger ones. Girls slept longer than boys, but the difference declined with age. Black children spent more time in other activities. As a result, they slept less than White children.

Out-of-school learning. Children in all family types read less than children in male breadwinnerfemale homemaker families. The amount of difference in reading time varied, however. The difference between children's reading time in a working-female-headed family and a male breadwinner-female homemaker family $(-2.09)$ was larger than the difference between a two-parent dual-earner and a male-breadwinner family $(-0.52)$. These differences reflect differences in time spent at home and availability of a second parent. Consistent with the emphasis on learning in the Asian community (Kao et al., 1996) and offsetting some of the lower time spent playing, Asian children spent significantly more time reading. In contrast, Black and Hispanic children spent significantly less time reading than White nonHispanic children. Older children spent time in other activities; consequently, reading for pleasure declined as children ages. Girls read less per week 
Table 3. Regressions of Achievement and Behavior Problems on Activities, With Controls for Family and CHILD BACKGROUND ${ }^{\mathrm{a}}$

\begin{tabular}{|c|c|c|c|c|c|c|c|}
\hline \multirow[b]{2}{*}{ Activity } & \multicolumn{4}{|c|}{ Woodcock-Johnson Achievement Test } & \multicolumn{3}{|c|}{ Behavior Problems } \\
\hline & $\begin{array}{c}\text { Letter-Word } \\
\text { Comprehension }\end{array}$ & $\begin{array}{c}\text { Passage } \\
\text { Comprehension }\end{array}$ & $\begin{array}{l}\text { Applied } \\
\text { Problems }\end{array}$ & Calculation & $\begin{array}{c}\text { Total } \\
\text { Behavior } \\
\text { Problems }\end{array}$ & $\begin{array}{l}\text { External } \\
\text { Behavior } \\
\text { Problems }\end{array}$ & $\begin{array}{c}\text { Internal } \\
\text { Behavior } \\
\text { Problems }\end{array}$ \\
\hline Intercept & $82.45^{*}$ & $89.84 *$ & $83.55^{*}$ & $88.30 *$ & $49.48 *$ & $28.71 *$ & $18.79 *$ \\
\hline Market work & 0.11 & 0.23 & 0.43 & $0.64 *$ & -0.07 & 0.01 & -0.08 \\
\hline Personal care & -0.11 & -0.06 & -0.09 & -0.07 & -0.02 & 0.01 & -0.02 \\
\hline Conversation & -0.19 & 0.47 & 0.06 & 0.84 & 0.17 & 0.09 & 0.06 \\
\hline Passive leisure & -0.11 & -0.01 & $-0.23^{*}$ & 0.01 & -0.03 & -0.02 & -0.01 \\
\hline Housework & -0.02 & 0.13 & 0.13 & -0.03 & -0.01 & -0.01 & 0.00 \\
\hline Eating & $0.32 *$ & 0.12 & $0.27 *$ & 0.14 & $-0.19 *$ & $-0.14 *$ & -0.04 \\
\hline Sleeping & -0.03 & -0.04 & -0.08 & -0.11 & -0.04 & -0.01 & $-0.03^{*}$ \\
\hline In school & 0.07 & 0.07 & $0.15^{*}$ & 0.12 & -0.04 & -0.03 & -0.02 \\
\hline Studying & 0.14 & 0.10 & 0.11 & 0.00 & 0.03 & 0.03 & 0.01 \\
\hline In church & 0.15 & 0.21 & 0.10 & 0.29 & -0.02 & -0.01 & -0.03 \\
\hline Visiting & $0.18 *$ & $0.21 *$ & $0.22 *$ & $0.25 *$ & -0.07 & -0.03 & -0.03 \\
\hline Playing sports & 0.02 & 0.08 & $0.20 *$ & 0.16 & $-0.07 *$ & $-0.04 *$ & -0.03 \\
\hline Outdoors & -0.16 & 0.09 & 0.01 & 0.12 & -0.00 & 0.03 & -0.03 \\
\hline Hobbies & 0.56 & 0.22 & 0.05 & -0.31 & -0.01 & -0.01 & -0.01 \\
\hline Art & 0.27 & 0.26 & 0.10 & -0.21 & -0.11 & -0.07 & -0.03 \\
\hline Playing & -0.04 & -0.02 & 0.06 & 0.06 & -0.00 & 0.01 & -0.01 \\
\hline Watching television & -0.04 & -0.01 & -0.03 & -0.01 & 0.00 & 0.01 & -0.01 \\
\hline Reading & $0.75 *$ & $0.53 *$ & $0.65^{*}$ & $0.58 *$ & -0.02 & -0.01 & 0.01 \\
\hline Day care & -0.07 & 0.13 & 0.12 & 0.10 & -0.02 & -0.01 & -0.01 \\
\hline$R^{2}$ & 0.21 & 0.21 & 0.25 & 0.17 & 0.07 & 0.07 & 0.08 \\
\hline$N$ & 1,726 & 1,218 & 1,719 & 1,211 & 2,121 & 2,121 & 2,121 \\
\hline
\end{tabular}

${ }^{\mathrm{a} C}$ Controls are age and gender of child, race and ethnicity, education and age of head, family structure and employment, income, and family size.

$* p<.05$.

than boys, but, with age, their reading time increased relative to that of boys. Not surprisingly, children of more-educated heads read more. It is likely that the parents read more themselves, had more books around the home, and encouraged their children to read.

Consistent with the previous results indicating that they read less for pleasure, older children studied more than younger children. Black, Hispanic, and Asian children spent more time studying than did White non-Hispanic children, net of other factors. Factors associated with parental nonemployment may also be linked to lower study time because we found that children study less in families in which there were two nonworking parents. Family income was not related to time spent studying; however, the education of the head was related. Children of better educated heads spent more time studying than did children of less-educated heads. Finally, children in families with an older head spent more time studying. Older parents were probably more knowledgeable about the importance of studying and encouraged their children to do so.

Children's television viewing was related to parental employment. Children in dual-earner families watched about 1 hour less television per week than did those with a male breadwinner. Such children spent less time at home during which they could watch television; they were likely to be in school or preschool. Race differences were striking. Black and Asian children watched considerably more television than did White, nonHispanic children, 22/3 hours more among Black, and almost 5 more hours per week among Asian children. Finally, parental education mattered. Children of better educated parents watched a half hour less television per week than did children of less-educated parents. Children of higher income parents also watched less television, although the effect is small.

\section{Association of Children's Time With Cognitive and Behavioral Outcomes}

In Table 3, we show the results of regressing achievement and behavior on children's activities. Although we cannot determine causality because activities and achievement are measured concurrently, we found numerous activities to be signif- 
icantly associated with scores on achievement tests and on the Behavior Problems Index and its subscales (not shown). These associations are primarily due to family factors affecting how children's time is spent. When demographic factors that affect how time is spent were included, only a few activities retain their significant association with cognitive achievement and behavior, and we focus only on those.

Time in learning activities was particularly important to achievement. Besides spending time in school, which was associated with higher scores on the applied problems test, spending more time reading for pleasure was strongly associated with higher scores on all achievement tests. Television and studying time were not associated with higher or lower scores on any tests.

Family time was important to both achievement and behavior. Spending more time eating meals was associated with a higher score on the letter-word and applied problems tests. It was also associated with a reduction in total, externalizing, and, marginally $(p<.10)$, internalizing problems. Time spent sleeping is associated with fewer internalizing behavior problems.

Active leisure was more productive than passive leisure. More time spent playing sports was associated with a higher score on the applied problems test and with reduced total behavior problems, externalizing problems, and, marginally $(p<.10)$, internalizing problems. Time spent visiting was associated with higher scores on all four cognitive tests. In contrast, time spent in passive leisure was associated with lower scores on the applied problems test.

\section{SuMmARY AND CONCLUSIONS}

In $1997,55 \%$ of an average child's week was spent eating, sleeping or in personal care, with an additional $15 \%$ spent in school or day care. This leaves only $30 \%$ of children's time as discretionary, the primary focus of our research. Of this 51 hours, free play comprised 15 hours per week (29\%) and television viewing about 12 hours per week $(24 \%)$ of their free time. In contrast, structured activities comprised 9 hours (18\% of free time) less than their time spent playing. Children spent little time in educational activities: 1 hour reading and 1 hour and 48 minutes studying. Art activities, household work, conversations, and other passive leisure complete the week.

One of the objectives of this research was to identify the factors associated with variation in how children spend time. Of the variety of activities in which children participate, we focused on four major categories of activities - school, structured and unstructured activities, out-of-school learning, and family time. In contrast to earlier research, we found consistent evidence that maternal employment affects children's time during the school year. Children spend more time in day care if they live with an employed mother. As a result, they spend less time in everything else, including play, structured activities such as church, family activities such as eating and sleeping, and learning time such as reading. They also watch television less.

Parental education, which reflects knowledge, preferences, and values, is positively related to educational activities such as reading and studying and negatively associated with television viewing. Family structure and size affect the ability of parents to monitor their children and the availability of playmates. Children from single female families spend less time in educational activities such as reading, regardless of the employment status of the parent. In contrast, they spend more time in structured sports. Children from larger families spend more time playing and in sports and less time visiting than children from smaller families; such children have a built-in set of playmates. Income is not as important as commonly believed. Family income was significantly associated only with the time children watch television (negatively) and the time spent eating meals and in day care (positively).

Race and ethnicity affects most activities. Many of the differences-such as the greater amounts of time that Asian children spend in educational activities at home, that Black children spend in church activities, and that Hispanic children spend in family activities such as eating and household work-were not surprising. More research on the sources of race and ethnic differences is needed.

Finally, keeping in mind that we cannot determine the causal direction of the effect, we asked whether time was associated with children's achievement and behavior. Of the three learning activities-reading, studying, and televisiononly reading was linked to achievement. We found that children who spent time reading for pleasure did better on tests of cognitive achievement. Studying may result as much from having difficulty in school as from motivation to excel; greater studying may characterize both low and high achievers. Although often negative in direc- 
tion, more television viewing was never significantly detrimental to children's achievement. Not surprisingly, spending more time in school was linked to higher achievement.

Structured activities were linked to both $\operatorname{cog}$ nitive and emotional development. Those who played sports were better problem solvers and had fewer emotional problems. Perhaps the cognitive skills learned on the playing field contribute to problem solving, and the social and physical skills developed contribute to better emotional adjustment. Alternatively, children lacking cognitive and social skills may not participate in sports activities. Involvement with others in visiting, which includes participation in youth organizations, was linked to greater achievement on all tests. Time spent playing per se was associated neither with achievement nor with behavior problems. Passive leisure was found to be associated with neither poorer test scores nor behavior problems; these findings support the conclusion that active forms of leisure promote children's development more than passive forms.

Time spent in family activities is associated with fewer problem behaviors. We found that children who spent more hours eating meals and sleeping had lower levels of behavior problems than did those who spent fewer hours eating or sleeping. During mealtime, children and parents can discuss what happened during the day. This is not the only time children and parents spend talking, but children spent only about 45 minutes sitting and talking as the main activity in 1997. Sleep is also important to children's well-being. Of course, it may be that children who have behavior problems both sit still and sleep less. This research was conducted at only one point in time. Longitudinal research is needed to demonstrate a causal relationship between activities and child achievement and behavior.

Parents often seek informed guidance as to how to direct their children's activities. This article has shown that the amount of time spent at home eating, sleeping, and reading is linked to children's achievement and behavior. Nonetheless, schools, day care centers, and before- and afterschool programs exert important influences on children's lives today as time spent at home declines. Out-of-home sports participation and visiting represent important aspects of children's lives both in the amount of time spent and in their relationship to cognitive and socioemotional wellbeing. As children spend less time at home, however, time spent reading, sleeping, and eating may decline. A balance of out-of-home and homebased activities may be desirable.

\section{Note}

Funding for this research was provided by Grant U01HD37563 from the National Institute of Child Health and Human Development and by the Center for the Ethnography of Everyday Life, an Alfred P. Sloan Center for the Study of Working Families. Thanks to Diana Blackford for research assistance.

\section{REFERENCES}

Anderson, D., Field, D., Collins, P., Lorch, E., \& Nathan, J. (1985). Estimates of young children's time with television: A methodological comparison of parent reports with time-lapse video home observation. Child Development, 56, 1345-1357.

Bianchi, S., \& Robinson, J. (1997). What did you do today? Children's use of time, family composition, and the acquisition of social capital. Journal of Marriage and the Family, 59, 332-244.

Blake, J. (1989). Family size and achievement. Berkeley: University of California Press.

Bredekamp, S., \& Copple, C. (1997). Developmentally appropriate practice in early childhood programs. Washington, DC: National Association for the Education of Young Children.

Fitzgerald, J., Gottschalk, P., \& Moffitt, R. (1998). An analysis of sample attrition in panel data: The Michigan Panel Study of Income Dynamics. Journal of Human Resources, 33, 251-299.

Fuligni, A. J., \& Stevenson, H. W. (1995). Time use and mathematics achievement among American, Chinese, and Japanese high school students. Child Development, 66, 830-842.

Gershuny, J., \& Robinson, J. P. (1988). Historical changes in the household division of labor. Demography, 25, 537-552.

Goldscheider, F. K., \& Waite, L. J. (1991). New families, no families. Berkeley: University of California Press.

Hanushek, E. (1989). The impact of differential expenditures on school performance. Educational Researcher, 18 (4),45-55.

Haveman, R., \& Wolfe, B. (1994). Succeeding generations: On the effects of investments in children. New York: Russell Sage Foundation.

Hofferth, S. (1996). Child care in the United States today. The Future of Children, 6 (2),41-61.

Hofferth, S. (1999, May). Family reading to young children: social desirability and cultural biases in reporting. Paper presented at the National Research Council Workshop on Measurement of and Research on Time Use, Committee on National Statistics, Washington, DC.

Juster, F., \& Stafford, F. P. (1985). Time, goods, and well-being. Ann Arbor, MI: Institute for Social Research.

Juster, F. T., \& Stafford, F. (1991). The allocation of time: Empirical findings, behavioral models, and problems of measurement. Journal of Economic Literature, 29, 471-522.

Kao, G., Tienda, M., \& Schneider, B. (1996). Racial and ethnic variation in academic performance. In A. M. 
Pallas (Ed.), Research in Sociology of Education and Socialization (pp. 263-297). Greenwich, CT: JAI Press.

Keith, T., Reimers, T., Fehrmann, P., Pottebaum, S., \& Aubey, L. (1986). Parental involvement, homework, and TV time: Direct and indirect effects on high school achievement. Journal of Educational Psychology, 78, 373-380.

Koolstra, C. M., \& Van Der Voort, T. H. (1996). Longitudinal effects of television on children's leisuretime reading: A test of three explanatory models. $\mathrm{Hu}$ man Communication Research, 23, 4-35.

Larson, R., \& Verma, S. (1999). How children and adolescents spend time across the world: Work, play, and developmental opportunities. Psychological Bulletin, 125, 701-736.

Longfellow, C. (1979). Divorce in context: Its impact on children. In G. Levinger \& O. Moles (Eds.), Divorce and separation: context, causes, and consequences (pp. 287-306). New York: Basic Books.

Marini, M. M., \& Shelton, B. A. (1993). Measuring household work: Recent experience in the United States. Social Science Research, 22, 361-382.

McDonald, J., \& Moffitt, R. (1980). The uses of Tobit analysis. Review of Economics and Statistics, 62, 318-321.

Medrich, E., Roizen, J., Rubin, V., \& Buckley, S. (1982). The serious business of growing up: A study of children's lives outside school. Berkeley: University of California Press.

Pellegrini, A., \& Smith, P. K. (1998). Physical activity play: The nature and function of a neglected aspect of play. Child Development, 69, 577-874.

Peterson, J. L., \& Zill, N. (1986). Marital disruption, parent-child relationships, and behavioral problems in children. Journal of Marriage and the Family, 48, 295-307.
Robinson, J. P. \& Bianchi, S. (1997). The children's hours. American Demographics, 20, 22-24.

Snow, C., Burns, M. S., \& Griffin, P. (1998). Preventing reading difficulties in young children. Washington, DC: National Academy Press.

Task Force on Youth Development and Community Programs. (1992). A matter of time: Risk and opportunity in the nonschool hours. New York: Carnegie Corporation.

Taylor, R. J., \& Chatters, L. M. (1988). Church members as a source of informal social support. Review of Religious Research, 30, 193-203.

Taylor, R. L. (1994). Minority families and social change. In R. L. Taylor (Ed.), Minority families in the United States: A multicultural perspective (pp. 204248). Englewood Cliffs, NJ: Prentice Hall.

Timmer, S. G., Eccles, J., \& O’Brien, K. (1985). How children use time. In F. Juster \& F. P. Stafford (Eds.), Time, goods, and well-being (pp. 353-382). Ann Arbor, MI: Institute for Social Research.

Tobin, J. (1958). Estimation of relationships for limited dependent variables. Econometrica, 26, 24-36.

U.S. Department of Education. (1999). Start early, finish strong: How to help every child become a reader [America Reads Challenge]. Washington, DC: Author.

Woodcock, R., \& Mather, N. (1989). W-J-R Tests of Achievement: Examiner's manual. In: R. W. Woodcock \& M. B. Johnson (Eds.), Woodcock-Johnson Psycho-Educational Battery-Revised. Allen, TX: DLM Teaching Resources.

Zajonc, R. B., \& Markus, G. B. (1975). Birth order and intellectual development. Psychological Review, 82, 74-88.

Zill, N., Collins, M., West, J., \& Hausken, E. (1995). Approaching kindergarten: A look at preschoolers in the United States (NCES 95-280). Washington, DC: U.S. Department of Education. 